\title{
20. APTYCHI (AMMONOIDEA) AND AMMONITES FROM THE LOWER CRETACEOUS OF THE WESTERN BERMUDA RISE, LEG 43, SITE 387, DSDP
}

\author{
Otto Renz, Museum of Natural History, Basel, Switzerland
}

\section{INTRODUCTION}

Sediments containing aptychi and several ammonites were recovered at Site 387 on the western Bermuda Rise in the western North Atlantic during Leg 43. Through the assistance of Dr. Ansis Kaneps (Scripps Institution of Oceanography, La Jolla, California) the material was sent to the Museum of Natural History in Basel.

Site 387 (latitude $32^{\circ} 19.2^{\prime} \mathrm{N}$, longitude $67^{\circ} 40^{\prime} \mathrm{W}$ ) is located $280 \mathrm{~km}$ west of Bermuda on the western Bermuda Rise, east of the Hatteras Abyssal Plain. Water depth at the site is 5118 meters and the hole penetrated 791.6 meters of sediment and 2.9 meters of underlying basalt.

The material discussed has been assembled from an interval of 3.97 meters within Sections 2 through 5 of Core 49 , at the base of the sedimentary sequence just above the basalt, at a sub-bottom depth of 788 to 792 meters. The combined thickness of the samples received is about $17 \mathrm{~cm}$, from which the astonishingly high number of 34 aptychi and four ammonites have been extracted. The assemblage of aptychi consists of 29 determinable specimens and is very diverse in comparison with those from equally short intervals at other sites in the Atlantic.

On the stratigraphical distribution chart (Figure 1), which encompasses the aptychus- and ammonite-bearing interval of Site 387, two assemblages of aptychi are distinguished. Assemblage 1 (left) comprises species belonging to different aptychus groups, and assemblage 2 (right) consists of those forms referable to the important Lamellaptychus mortilleti group. The predominance of specimens assumed to be related to $\mathrm{L}$. mortilleti is eminent ( 18 specimens versus 11 belonging to different groups of aptychi). They represent 7 versus 9 species, respectively.

Conspicuous features defining the mortilleti group, which ranges throughout the interval, are its abundance and the great diversification of forms displaying the following common pattern of lamellae: the more or less flexuous curved lamellae bend towards the symphysal edge, which they follow in this direction to the ventral termination of the valve. This pattern is characteristic of the lectotype (Plate 1, Figure 16) of Lamellaptychus mortilleti (Pictet and Loriol). We thus might refer to this interval as the "mortilleti zone," and this will certainly represent a valuable stratigraphic guide for future investigations.

It is of importance to note that only a small proportion ( 7 specimens) of the available forms can be readily identified; they are known from the Alpine-

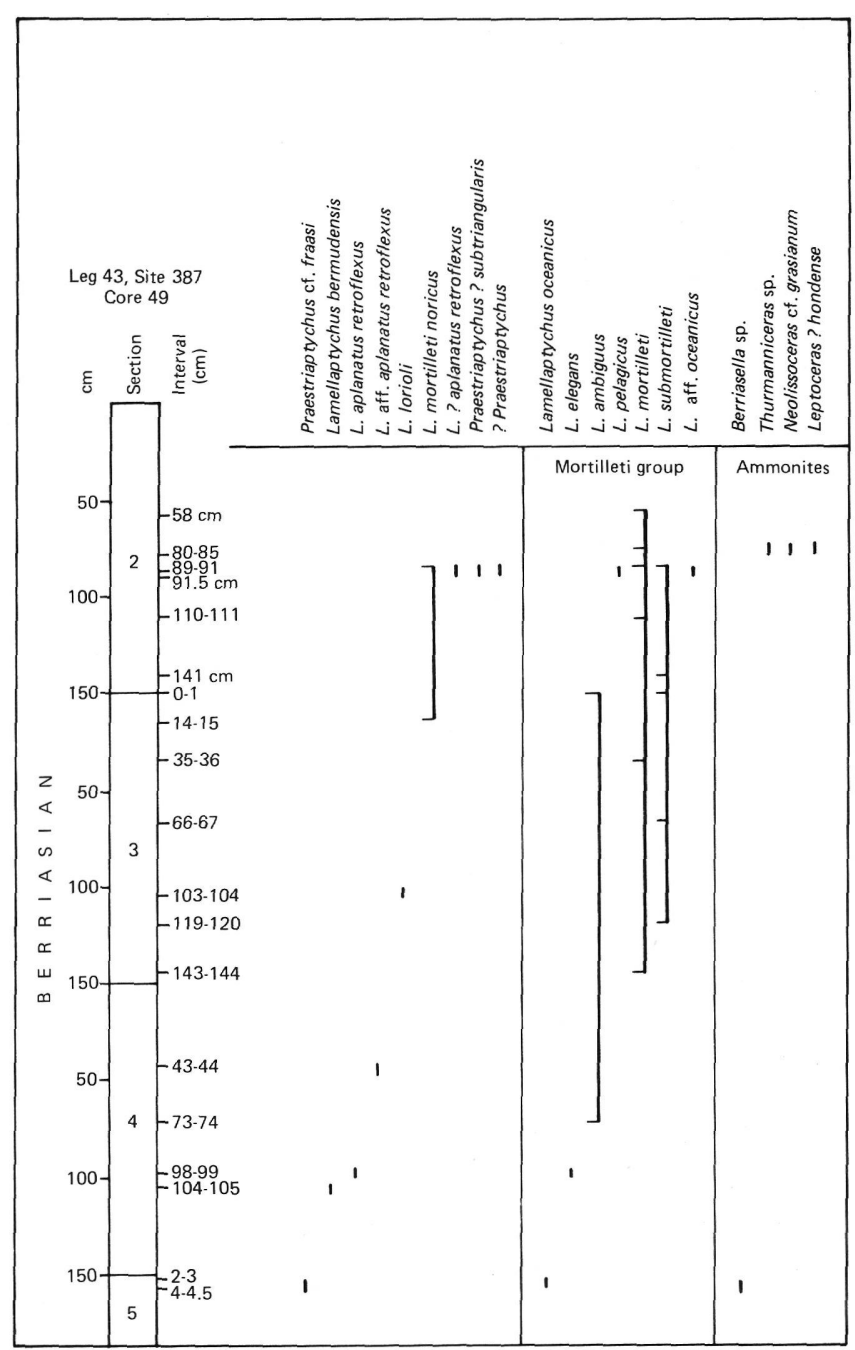

Figure 1. Distribution chart of aptychi from Leg 43, Site 387, Core 49.

Mediterranean facies province or elsewhere. The greater number ( 9 specimens) have, as far as we know, not yet been described. A better understanding concerning the stratigraphic position of the present fauna will certainly be obtained by additional finds, which might clarify the relationships between assemblages from the upper Tithonian below and the Lower Cretaceous (Valanginian-Hauterivian) above.

\section{AGE}

The abundant undescribed forms of aptychi are at present of little value for age determination, and we 
therefore have to rely on known age indicative species; these are, from bottom to top:

Praestriaptychus cf. fraasi Trauth, Upper JurassicLower Cretaceous (Plate 1, Figure 1a,b).

Lamellaptychus bermudensis n. sp. (holotype, Plate 1, Figure 2). This species is related to Lamellaptychus indet. 1, Renz 1977, juvenile specimen from Leg 41, Sample 367-31-2, 2-3 cm; Plate 1, Figure 23a,b, Lower Cretaceous.

Lamellaptychus aplanatus rectoflexus Trauth, Berriasian (Plate 1, Figure 3a,b).

Lamellaptychus mortilleti noricus Trauth, Berriasian (Plate 1, Figures 6, 7).

Lamellaptychus mortilleti (Pictet and Loriol), Berriasian (Plate 1, Figures 16-22).

On the basis of aptychi, we might best assume a Berriasian age for this short interval, as typical Tithonian and lower Valanginian forms were not observed.

Besides the aptychi, four ammonite genera could be identified. They are, from bottom to top:

Berriasella sp., Sample 49-5, 4-4.5 cm (Figure 2a). $2 \mathrm{e})$.

Thurmanniceras sp., Sample 49-2, 80-85 cm (Figure

Neolissoceras cf. grasianum (d'Orbigny), Sample 49-2, 80-85 cm (Figure 2b).

Leptoceras ? hondense Imlay, Sample 49-2, 80-85 $\mathrm{cm}$ (Figure 2c, d).

The genus Berriasella Uhlig, 1905, belongs to the family Berriasellidae, and it has a worldwide distribution in the upper Tithonian to Berriasian.

Thurmanniceras also belongs to this family and it lived during Berriasian to early Valanginian times.

Neolissoceras cf. grasianum (d'Orbigny) forms part of the family Haploceratidae. The species is common and long ranging and occurs in the upper Tithonian to Hauterivian.

Five small specimens resembling Leptoceras ? hondense Imlay, known from the Viñales Limestone in Cuba, are present.

The Berriasian date based on aptychi is thus confirmed by the scarce ammonite remains present.

\section{TENTATIVE CORRELATIONS WITH SITES 105 (LEG 11) AND 367 (LEG 41)}

One of the aims of the present report is to establish the relationships between the Leg 43 association of aptychi with other occurrences in the Atlantic. Thus far, assemblages of aptychi have been recovered at Site 105 of Leg 11, drilled at the foot of the continental rise near the northern end of the Hatteras Abyssal Plain, and at Site 367 of Leg 41, situated southeast of the Cape Verde Islands in the Cape Verde Basin.

Site 105 (latitude $34^{\circ} 53.73^{\prime} \mathrm{N}$, longitude $69^{\circ} 10.40^{\prime} \mathrm{W}$ ) is located $320 \mathrm{~km}$ northwest of Site 387 and $500 \mathrm{~km}$ northwest of Bermuda. This hole yielded two distinctly different assemblages of aptychi, separated by a 128-meter-thick barren interval. The lower fauna (Cores 33 and 36) occurs in sediments comparable to the Rosso ad Aptychi Formation of the Tethyan facies province. It comprises eight species that indicate a Late Jurassic date, presumably Oxfordian to Titho- nian. The younger assemblage (from Core 18) is Hauterivian.

At Site 367, in the Cape Verde Basin (latitude $12^{\circ} 29^{\prime} \mathrm{N}$, longitude $20^{\circ} 03^{\prime} \mathrm{W}$ ), a succession of four assemblages was recovered, ranging from upper Oxfordian to Hauterivian; they span a 240-meter-thickness of sediment (910-1150 m below the sea floor). Of special interest for the present report are the assemblages recovered from the top of Core 31, thought to represent the transition from upper Tithonian to lower Berriasian, and those from Core 34, assumed to be Kimmeridgian. A partly cored interval about 33 meters thick separates these two assemblages. I assume at present that the lower Berriasian Leg 43 fauna here described, belongs below the assemblage of Core 31 , and that it could be expected in the uncored interval separating Core 31 from Core 32 of Site 367. Noteworthy is the fact that only one species of the Lamellaptychus bermudensis group (equal to Lamellaptychus indet. 1 in Site 367, Figure 1) has also been recorded among the numerous specimens of the Leg 43 assemblage. This suggests that aptychi have restricted stratigraphic ranges, and therefore will be of considerable help for correlations between holes in the future.

\section{PALEONTOLOGICAL DESCRIPTIONS}

The sediment of the aptychus-bearing interval is predominantly light gray, chalky, finely porous limestone containing abundant euhedral calcite of apparently diagenetic origin.

The majority of specimens are surprisingly well preserved and could be readily freed from the sediment. Some thin-shelled valves have been affected by compaction of the sediment. After preparation, a conspicuous diversity of forms appeared, even suggesting the presence of a biostratigraphic boundary within this short interval, indicated by the first appearance of Lamellaptychus mortilleti (Pictet and Loriol) in Sample 49-4, 143-144 cm.

The following descriptions are arranged, as far as possible, stratigraphically from oldest to youngest.

\section{APTYCHI}

Praestriaptychus ef. fraasi Trauth

(Plate 1, Figure 1a, b)

Praestriaptychus fraasi Trauth, 1937, p. 138, pl. 10, fig. 1-7.

Sample 49-5, 4-4.5 $\mathrm{cm}$. This moderately well preserved, very delicate, thin-shelled pair of valves is exposed on its concave side. The outer parts of the valve are partly destroyed but nevertheless their subtriangular outline is recognizable. The concave surface is coated by a very thin film of a dark brown, apparently chitinous (to coaly) substance, which also has been mentioned by Trauth (1937, p. 136-138). Its outstanding features are equidistant fine radial striae crossing fan-like over the concave side of the valve from the apical region towards the ventral margin (Plate 1, Figure $1 b$ ). On the convex side this striation is not exposed. The present specimen resembles Praestriaptychus inverselobati (Weerth), 1884, p. 26, pl. 7, fig. 2 from Neocomian marls in the Teutoburger Wald in Germany.

\section{Lamellaptychus bermudensis $\mathrm{n}$. $\mathbf{s p}$.}

(Plate 1, Figure 2)

Sample 49-4, 104-105 cm, holotype. This perfectly preserved left valve resembles a juvenile pair of valves obtained from Leg 41 material (Sample 367-31-2, 2-3 cm) from the Cape Verde Basin (Renz, 1978, pl. 1, fig. 23a, b). Owing to its small size, it was provisionally labeled "Lamellaptychus indet. 1." The present specimen is characterized by a very prominent ridge-like keel, over which the lamellae forming lengthened inflexions are clearly effaced. They meet the symphysis at right angles, a character that distinguishes this 
species from Lamellaptychus aff. herthae (Winkler) from Leg 41, Site 367 (Renz, 1978, pl. 1, fig. 31,32). Between this keel and the lateral margin the valve is conspicuously depressed, as on Lamellaptychus excavatus Trauth (1938, p. 178, pl. 12, fig. 31). Its width to length ratio ( $=$ width-index) reaches 0.50 .

\section{Lamellaptychus aplanatus retroflexus Trauth}

(Plate 1, Figure 3a,b)

Lamellaptychus aplanatus var. retroflexa Trauth, 1938, p. 193, pl. 13 , fig. 24, 25.

Sample 49-4, 98-99 $\mathrm{cm}$. This specimen differs from Lamellaptychus aplanatus (Gilliéron) as found in the Cape Verde Basin (Sample 41-367-31-2, 2-3 cm, Renz, 1978, pl. 1, fig. 25a,b) by its backwardly curved lamellae in the vicinity of the symphysal rim. The lamellae follow about parallel to the lateral margin as on $\mathrm{L}$. aplanatus. As reconstructed (Plate 1, Figure $3 b$ ), the width-index is 0.60 against 0.50 to 0.53 (Trauth, 1938, p. 193).

Trauth recorded this form from a light red Tithonian limestone from the Carpathians, together with $\mathrm{L}$. aplanatus.

\section{Lamellaptychus aff. aplanatus retroflexus Trauth}

(Plate 1, Figure 4)

Sample $49-4,43-44 \mathrm{~cm}$. This pair of valves belonging to the L. aplanatus group appeared $55 \mathrm{~cm}$ above the specimen of $\mathrm{L}$. aplanatus retroflexus. It differs from a typical L. aplanatus retroflexus by its last-formed lamellae ending along the ventral margin. The backward turning of the lamellae at that stage begins noticeably closer to the symphysis than on a typical L. aplanatus rectoflexus (compare pl. 1, fig. 3 in this report). Width-index $=0.51$.

\section{Lamellaptychus lorioli $n$. sp. (Plate 1, Figure 5a)}

Aptychus Seranonis Coquant, Pictet, 1867, p. 123, pl. 28, fig. 9 b. Lamellaptychus seranonis (Coquant), Trauth, 1938, p. 193, pl. 13, fig. 29.

Sample 49-3, 103-104 cm. The similarity of the present specimen with a valve from Berrias in the Ardèche illustrated by Pictet ( 1867 , pl. 28 , fig. 9 b, ca. $1.5 \times$ ), and reproduced by Trauth (1938, pl. 13, fig. 29), seems obvious.

On this adult specimen the backwardly curved lamellae are approximately parallel to the lateral margin, and the last ones do not end against the ventral margin as is usual on adult L. seranonis. Instead of the pronounced keel that characterizes L. seranonis, the valve is broadly convex from the apex toward the ventral margin. The width-index reaches 0.52 in comparison with 0.48 for the specimen from the Ardèche. There are thus good reasons not to identify this specimen as L. seranonis, which presumably occurs at stratigraphically higher levels.

\section{Lamellaptychus mortilleti noricus Trauth}

(Plate 1, Figures 6, 7)

Lamellaptychus mortilleti noricus Trauth, 1938, p. 190, pl. 13, fig. 16.

Lamellaptychus mortilleti noricus Trauth, Gasiorowski, 1962, pl. 7, fig. 1 .

Sample 49-3, 14-15 cm, and Sample 49-2, 89-91 cm (juvenile specimen). These rather small valves, which are broadly subrectangular in outline, reach a width-index of 0.52 , against 0.53 of the specimen figured by Trauth. A broad keel extending from the apex to the junction of the lateral and ventral margins is more pronounced on the right valve, on which a depression of the valve, causing a slight indentation of the lateral margin, is also better developed. This form is characterized by densely spaced lamellae, which follow the lateral margin, and bend near the symphysal border toward the ventral end of the valve.

Trauth (1938, p. 190) mentioned this form from Neocomian marls near Kufstein in Austria. In the Carpathians, Gasiorowski listed it from horizon 7, which corresponds with the Berriasian.

\section{Lamellaptychus? aplanatus retroflexus Trauth} (Plate 1, Figure 8a)

Sample 49-2, 89-91 cm. This specimen resembles Lamellaptychus aplanatus retroflexus Trauth, from which it is stratigraphically separated by a thickness of 1.50 meters of sediment. The two forms, obviously, might belong to related ammonite species. Termination of the lamellae along the lateral and ventral margins distinguishes the present specimen from typical L. aplanatus retroflexus. This feature also characterizes Lamellaptychus seranonis (Coquand), which, however, possesses a prominent keel followed by a depression of the valve. The retroverse turning of the lamellae occurs close to the symphysis. At 0.60 , the width-index is the same as that for $\mathrm{L}$. aplanatus retroflexus (Plate 1, Figure 3).

\section{Praestriaptychus? subtriangularis Trauth}

(Plate 1, Figure 9)

Trigonellites radians Ooster, 1863, p. 9, pl. C, fig. 1 Praestriaptychus subtriangularis Trauth, 1937, p. 148, pl. 11, fig. 3,4 .

Sample 49-2, 89-91 cm. This small, thin-shelled, flat pair of valves is subtriangular in outline and resembles Ooster's drawing ( $\mathrm{pl}$. C, fig. 1), which according to Trauth (1937, p. 149) represents the concave side of the valve. The present specimen shows the convex surface, which appears uneven to wrinkled and ornamented with shallow ribs that meet the symphysal rim at right angles. A fragment showing the concave side displays fine, narrowly spaced growth lines, but no radial striation. Better preserved material is needed to characterize this form more fully.

\section{?Praestriaptychus}

(Plate 1, Figure 10)

Sample 49-2, 89-91 cm. The assignment of these small rectangular valves to Praestriaptychus is problematic owing to their poor preservation. The flattened convex surface seems uneven and dotted with small pores.

\section{GROUP OF LAMELLAPTYCHUS MORTILLETTI (PICTET AND LORIOL)}

They are characterized by a pattern of lamellae that is observed here for the first time in the Atlantic. The lamellae are more or less conspicuously inflected twice, once over the keel (when present), and again between the keel and the symphysal edge. They follow the symphysis in the direction of the ventral end of the valve.

\section{Lamellaptychus oceanicus n. sp.}

(Plate 1, Figure 11a,b)

Sample 49-5, 2-3 cm, holotype. This specimen seems obviously related to Lamellaptychus mortilleti (Pictet and Loriol), as suggested by its pattern of lamellae and subrectangular outline. Its width index after reconstruction is 0.48 in comparison with $0.43-0.44$ for $\mathrm{L}$. mortilleti. A further feature in common is the lengthened sigmoidal approach of the lamellae against the symphysal border, which they follow in direction to the ventral end of the valve. The species differs from L. mortilleti by the course of the lamellae being parallel to the lateral and ventral margins, and by their convergence in the vicinity of the ventral termination of the valve. Over the pronounced keel the last lamellae display right-angle bends, similar to but less conspicuous than those on Lamellaptychus elegans n. sp., discussed below.

\section{Lamellaptychus elegans n. sp. \\ (Plate 1, Figure 12a,b)}

Sample 49-4, 98-99 cm, holotype. This distinct form is domirated by a very pronounced keel that declines steeply toward the lateral margin and more gently toward the symphysis. Owing to the steep slope of the keel, the surfaces of the lamellae are broadly exposed in a direction toward the lateral margin. Along the crest of the keel the latest formed lamellae display asymmetric acute-angle inflexions, and they do not converge toward the ventral end of the valve as in L. oceanicus (described above). The latest formed lamellae end against the ventral margin of the valve. On the basis of a tentative reconstruction, the width index might reach 0.47 .

Lamellaptychus ambiguus $n$. sp.

(Plate 1, Figures 13a,b, 14)

Sample 49-3, 0-1 cm, holotype, and Sample 49-4, 73-74 cm. This most striking specimen, with its destroyed lateral side reconstructed, 
resembles Lamellaptychus beyrichodidayi Trauth (1938, p. 200, pl. 14, fig. 5) from the Neocomian of Barrême in the Département Basses Alpes in France. The present specimen actually combines features of two entirely different groups of Lamellaptychi. The dorsal half of the valve displays conspicuously the features of a Lamellaptychus of the mortilleti group, while the ventral half is indistinguishable from a Lamellaptychus didayi (Coquand), (Plate 1, Figure 14). The change between the two arrangements of the lamellae occurs mainly along the symphysis in about the middle of the valve within the short interval of three lamellae. On the dorsal half of the valve the widely spaced lamellae are broadly sigmoidally curved and follow the symphysis toward the ventral end of the valve, as typical for a representative of the L. mortilleti group. This pattern suddenly changes and the lamella (indicated by an arrow) meets the symphysis at an angle of about $55^{\circ}$. The next younger four lamellae are conspicuously broadly curved backwards towards the apex. Simultaneously, the lamellae become wider spaced and turn from a rather flat position to vertical, as is typical for the Lamellaptychus didayi group.

The present form differs from Lamellaptychus beyrichodidayi in its broadly flexuous curved lamellae on the ventral half of the valve, which seem to parallel the ventral margin, and by the absence of inflected lamellae over the broad diagonal elevation. Nevertheless, the French and the Atlantic specimens seem to be closely related, and probably belong to the same ammonite genus.

The possibility that $\mathrm{L}$. ambiguus belongs to an ammonite species, which in the course of its ontogenetic development displays features of two ammonite genera, cannot be excluded.

\section{Lamellaptychus pelagicus $\mathbf{n}$. sp.}

(Plate 1, Figure 15a,b)

Sample 49-2, 89-91 cm, holotype. This partly and imperfectly preserved specimen was extracted from a calcilutite (carbonate content 60 per cent) containing terrigenous debris (small quartz grains and mica flakes). Well-developed calcite rhombohedra of diagenetic origin are abundant. The reconstruction of the valve can be regarded as reliable. It has a subtriangular outline with a widthindex of about 0.53 . It is diagonally crossed by a low and broadly arched elevation. The lamellae display two long, flexuous bends, one over the elevation, and another approaching the symphysis. The lateral facet is exceptionally broad, and flattens out toward the lateral margin, filling the indentation caused by the depression of the valve (flat area is dotted on Plate 1, Figure 15b). The dorsal margin of the valve is bounded by a relatively broad, thin-shelled, even plate, against which the lamellae end abruptly. This form is presumably also related to the mortilleti group.

\section{Lamellaptychus mortilleti (Pictet and Loriol)}

(Plate 1, Figure 16, lectotype; 17-22)

Aptychus Mortilleti Pictet and Loriol, 1858, p. 50, pl. 11, fig. 9b-d.

Lamellaptychus mortilleti (Pictet and Loriol), Trauth, 1938, p. 145, pl. 10 , fig. 30 .

Lamellaptychus mortilleti (Pictet and Loriol), Stefanov, 1961, p. 280 , pl. 3 , fig. 2 .

Lamellaptychus mortilleti (Pictet and Loriol), Gasiorowski, 1962, pl. 7 , figs. 7,10 .

Sample 49-3, $143-144 \mathrm{~cm}, 66-67 \mathrm{~cm}$ and $35-36 \mathrm{~cm}$

Sample $49-2,110-111 \mathrm{~cm}, 89-91 \mathrm{~cm}, 80-85 \mathrm{~cm}$ (2 individuals), and $58 \mathrm{~cm}$.

This species and the closely related Lamellaptychus submortilleti Trauth are the most widely distributed Lamellaptychi of the assemblage. They occur at nine levels and this interval may be referred to as the "mortilleti-interval."

This form has been imprecisely defined by previous authors. Trauth included different forms of aptychi in this species. Therefore, I here propose the specimen shown on Plate 11, Figure 9d by Pictet and Loriol (1858) from the Montagne des Voirons near Geneva, as lectotype.

The outline of the valve is elongate and subrectangular. Its widthindex ranges from 0.42 to 0.44 ( 3 specimens). The apical angle is slightly greater than $90^{\circ}$. A broadly arched keel (or elevation) extends from the apical region diagonally to the junction between lateral and ventral margin. It is followed by a very shallow depres- sion causing a slight indentation along the lateral margin of the valve. The lamellae form elongated flexuous bends over this elevation, and when approaching the symphysis they conspicuously turn towards the ventral end of the valve.

L. mortilleti has been recorded by Trauth from the Tithonian and Neocomian of the Alps. The drawings of Gasiorowski (pl. 7, fig. 7, 10) coincide well with the present valves. In the Carpathians this species occurs in horizon 7 of the Berriasian.

\section{Lamellaptychus submortilleti Trauth \\ Plate 1, Figures 23-26)}

Lamellaptychus submortilleti Trauth, 1938, p. 143, fig. 23, 25. Lamellaptychus submortilleti Trauth, Gasiorowski, 1962, pl. 6, fig. 13,18 .

Sample 49-3, 119-120 $\mathrm{cm}$ and 0-1 cm.

Sample 49-2, $141 \mathrm{~cm}$, and $89-91 \mathrm{~cm}$ (4 specimens),

Lamellaptychus submortilleti differs from $\mathrm{L}$. mortilleti by the absence of a keel and a flank depression. The valve is flat and crossed by the lamellae without inflexions. Width index is 0.45 to 0.55 ( 4 specimens), in comparison with 0.40 to 0.67 obtained by Trauth.

The form is widely known from the Alpine-Mediterranean region. According to Trauth, it occurs scarcely in the Tithonian, but frequently in the Neocomian of Austria, Switzerland, and France (Neocomian marls of Barrême, Basses Alpes). Gasiorowski records it from horizon 6 of the upper Tithonian in the Carpathians.

\section{Lamellaptychus aff. oceanicus Renz (Plate 1 Figure 27)}

Sample 49-2, $91.5 \mathrm{~cm}$. This fragment was recovered 3.60 meters above the holotype of L. oceanicus n. sp., from which it differs by the absence of a prominent keel. It has instead a broadly arched elevation, that crosses the valve diagonally. The irregularly curved lamellae cross the elevation without inflexions. The lamellae typically converge near the ventral end of the valve.

\section{AMMONOIDEA}

\section{? Berriasella sp. (Figure 2[A])}

Sample 49-5, 4-4.5 cm. A flattened, pyritized, quarter whorl of an ammonite, presumably representing Berriasella (Perisphinctaceae), reaches a whorl-height of $12 \mathrm{~mm}$. It is separated from the Praestriaptychus cf. fraasi Trauth by a sediment thickness of about $4 \mathrm{~mm}$. The distinctly sharp biplicate ribs separated by deep furrows are clearly exposed. Imlay (1942, p. 1456, pl. 8, fig. 2, 3) designates a similar fragment from the Viñales Limestone in Cuba as Berriasella? sp.

The white, chalky limestone with radiolarians of Samples 45-2, $80-85 \mathrm{~cm}$, which yielded nine specimens of ammonites, contains abundant euhedral calcite. These crystals are densely accumulated on the surfaces of ammonites, but are absent on the surface of aptychi, suggesting that they were formed from carbonates derived from the ammonite shells. Owing to these less compact layers of crystals, it is possible to separate the surface of an ammonite from its surrounding somewhat harder sediment.

\section{? Thurmanniceras sp.}

(Figure 2[E])

Sample $45-2,80-85 \mathrm{~cm}$. This genus seems to be represented by two fragments, whose combined features permit a reconstruction of the whorl section and rib-pattern. The width to height ratio is about 0.84 . Venter flat and clearly shouldered. Flanks gently convex. Umbilical wall about vertical. Ribs prominent and slightly raised to low, elongated tubercles near the umbilical edge, and before ending on the venter. Some of the ribs exposed bifurcate around the middle of the flank, others remain single. Toward the venter the ribs curve adorally.

\section{Neolissoceras cf. grasianum (d'Orbigny)} (Figure 2[B])

Sample 45-2, 80-85 $\mathrm{cm}$. One small and undeformed ammonite appeared when searching the available material. Measurements: diameter, $14.6 \mathrm{~mm}$, whorl-height, $7.3 \mathrm{~mm}(0.50)$, whorl-width about 

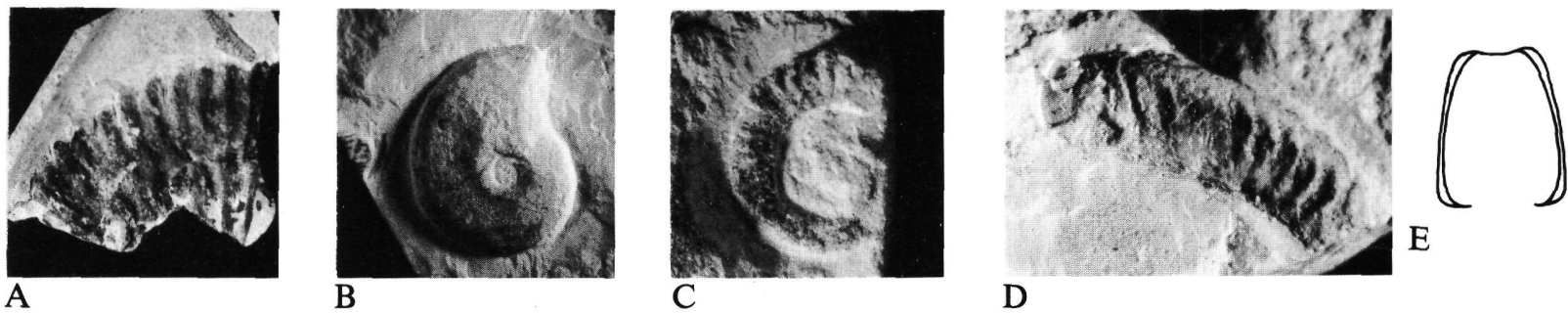

Figure 2. (A-C) Ammonoidea. (A) Section 5, 4-4.5 cm: ? Berraisella sp., $1.5 \times$. (B) Section 2, $80-85 \mathrm{~cm}$ : Neolissoceras $c f$. grasianum (d'Orbigny), $1.5 \times$. (C, D) Section 2, 80-85 cm: Leptoceras ? hondense dImlay, $2 \times$. (E) Section 2, 80-85 cm: ? Thurmanniceras, $2 \times$.

$3 \mathrm{~mm}(0.20)$, umbilicus, $2.1 \mathrm{~mm}(0.15)$. Flanks flat (? partly very slightly concave), shoulder and venter rounded. Umbilical edge well marked and umbilical wall moderately inclined toward the narrow umbilicus (about $45^{\circ}$ ). No ornamentation and no suture lines visible. The specimen resembles closely a similar small specimen of $N$. grasianum (d'Orbigny) from the Valanginian of the Swiss Alps.

\section{Leptoceras ? hondense Imlay} (Figures 2[C, D])

Leptoceras ? hondense Imlay, 1942, p. 1456, pl. 10, fig. 5-9, 11, 12.

Sample 45-2, 80-85 cm. In spite of the limited amount of material examined, six small specimens of this uncoiled ammonite could be recognized. The accumulation of specimens is similar to its occurrence in the Viñales Limestone of Cuba as shown by Imlay (1942, pl. 10, fig. 12). With the exception of one fragment (Figure 2[D]) all specimens are very much compressed and damaged. Coiling crioceratid, whorls widely separated, higher than wide and oval in section (Figure 2[D]). Ribs radial, prominent on the flank but diminishing toward the venter, where they seem to disappear.

\section{ACKNOWLEDGMENTS}

The writer is especially grateful to Dr. J. Saunders for reviewing the manuscript, and for the benefit gained from extensive discussions. I also acknowledge the assistance of $\mathrm{W}$. Suter who prepared the photographs.

\section{REFERENCES}

Coquand, M., 1841, Mémoire sur les Aptychus: Soc. Géol. France Bull., v. 12, p. 376-391.

Gasiorowski, S. M., 1962. Aptychi from the Dogger, Malm and Neocomian in the Western Carpathians and their stratigraphical value: Studia Geol. Polonica, v. 10, p. $1-144$

Imlay, R. W., 1942. Late Jurassic fossils from Cuba and their economic significance: Geol. Soc. Am. Bull., v. 53, p. $1417-$ 1478.

Ooster, W. A., 1857. Catalogue des céphalopodes fossiles des Alpes Suisses avec la description et les figures des espèces remarquables: Part 2, p. 1-32.

, 1863. Petrifications remarquables des Alpes Suisses, céphalopodes nouvellement découverts. Supplément part. 4, p. 1-31.
Pictet, F. J., 1867. Mélange paléontologiques. Etudes paléontologiques sur la faune à Terebratula diphyoides de Berrias (Ardèche). Mém. soc. phys. et hist. nat. Genève, v. 17, p. 43-130.

Pictet, F. J. and Loriol, P., 1858. Description des fossiles contenus dans les terrains néocomiens des Voirons: Mat. paléont. Suisse, sér. 2, p. 1-64.

Renz, O., 1972. Aptychi (Ammonoidea) from the Upper Jurassic and Lower Cretaceous of the western North Atlantic (Site 105, Leg 11, DSDP). In Hollister, C. D., Ewing, J. I., et al., Initial Reports of the Deep Sea Drilling Project, v. 11: Washington (U.S. Government Printing Office), p. 607-629.

1978. Aptychi (Ammonoidea) from the Late Jurassic and Early Cretaceous of the Eastern Atlantic, south of the Cape Verde Islands (Leg 41, Site 367, DSDP). In Lancelot, Y., Seibold, E., et al., Initial Reports of the Deep Sea Drilling Project, v. 41: Washington (U.S. Government Printing Office), p. 499-514.

Stefanov, J., 1961. Ammonoid Operculums (Aptychi) from the Lower Cretaceous of Bulgaria: Trav. Géol. Bulgarie, v. 3, Sofia, p. 210-235.

Trauth, F., 1937. Die Praestriaptychi und Granulaptychi des Oberjura und der Unterkreide: Palaeont. Z., v. 19, p. 134162.

, 1938. Die Lamellaptychi des Oberjura und der Unterkreide: Palaeontographica, Abt. A, v. 88, p. 115229.

Weerth, O., 1884. Die Fauna des Neocomsandsteins im Teutoburger Walde: Palaeont. Abh., v. 2, p. 1-77.

\section{APPENDIX}

Lamellaptychi from the Betic Cordillera in southern Spain were recently investigated. They derive from a pelagic limestone of Berriasian age exposed near Archidona, and were collected by $\mathbf{M}$. Blumenthal. Several of the valves are identical with new species introduced in the present report. Some specimens are: Lamellaptychus mortilleti (Pictet and Loriol)

Lamellaptychus aff. oceanicus $n$. sp.

Lamellaptychus elegans $n$. sp.

Lamellaptychus ambiguus $\mathrm{n}$. $\mathrm{sp}$.

The observation supports a Berriasian age for the aptychi-bearing interval at Site 387. 
PLATE 1

Site 387 , Core 49

Figure 1a Section 5, 4-4.5 cm: Praestriaptychus cf. fraasi Trauth, concave side, $3 \times$.

Figure 2 Section 4, 104-105 cm: Lamellaptychus bermudensis n.sp., holotype, $1.5 \times$.

Figure 3a Section 4, 98-99 cm: Lamellaptychus aplanatus rectoflexus Trauth, $1.5 \times$.

Figure $3 b \quad$ Reconstruction, $1.5 \times$.

Figure 4 Section 4, 43-44 cm: Lamellaptychus aff. aplanatus retroflexus Trauth, $2.5 \times$.

Figure 5a Section 3, 103-104 cm: Lamellaptychus lorioli n.sp., $1.5 \times$.

Figure $5 b \quad$ Reconstruction, $1.5 \times$.

Figure 6 Section 3, 14-15 cm: Lamellaptychus mortilleti noricus Trauth, $4 \times$.

Figure 7 Section 2, 89-91 cm: Lamellaptychus mortilleti noricus Trauth, juvenile stage, $4 \times$.

Figure 8a Section 2, 89-91 cm: Lamellaptychus ? aplanatus retroflexus Trauth. In the upper left corner a juvenile Lamellaptychus submortilleti Trauth, $1.5 \times$.

Figure $8 \mathrm{~b} \quad$ Reconstruction, $1.5 \times$.

Figure 9 Section 2, 89-91 cm: Praestriaptychus ? subtriangularis Trauth, convex side, $4 \times$.

Figure 10 Section 2, 89-91 cm: ? Praestriaptychus, $4 \times$.

Figure 11a Section 5, 2-3 cm: Lamellaptychus oceanicus n.sp., holotype, $2.5 \times$.

Figure $11 \mathrm{~b}$ Reconstruction, $2.5 \times$.

Figure 12a Section 4, 98-99 cm: Lamellaptychus elegans n. sp., holotype, $1.5 \times$.

Figure $12 \mathrm{~b}$ Reconstruction, $1.5 \times$.

Figure 13a Section 3, 0-1 cm: Lamellaptychus ambiguus $\mathrm{n}$. sp., holotype, $1.5 \times$.
Figure 13b Reconstruction, $1.5 \times$.

Figure 14 Section 4, 73-74 cm: Lamellaptychus ambiguus n. sp., $1.5 \times$.

Figure 15a Section 2, 89-91 cm: Lamellaptychus pelagicus n. sp., holotype, $2 \times$.

Figure $15 \mathrm{~b}$ Reconstruction, $2 \times$.

Figure 16 Lamellaptychus mortilleti (Pictet and Loriol), 1858, p. 50, pl. 11, fig. 9, lectotype.

Figure 17 Section 3, 35-36 cm: Lamellaptychus mortilleti (Pictet and Loriol), $2 \times$.

Figure 18 Section 3, 143-144 cm: Lamellaptychus mortilleti (Pictet and Loriol), $3 \times$.

Figure 19 Section 3, 66-67 cm: Lamellaptychus mortilleti (Pictet and Loriol), $3 \times$.

Figure 20 Section 2, $58 \mathrm{~cm}$ : Lamellaptychus mortilleti (Pictet and Loriol), $2 \times$.

Figure 21 Section 2, 80-85 cm: Lamellaptychus mortilleti (Pictet and Loriol), together with Leptoceras ? hondense Imlay, $2 \times$.

Figure 22 Section 2, 80-85 cm: Lamellaptychus mortilleti (Pictet and Loriol), $2 \times$.

Figure 23 Section 3, 119-120 cm: Lamellaptychus submortilleti Trauth, juvenile specimen, $4 \times$.

Figure 24a Section 2, 89-91 cm: Lamellaptychus submortilleti Trauth, $2 \times$.

Figure 24b Reconstruction, $1.5 \times$.

Figure 25 Section 2, 89-91 cm: Lamellaptychus submortilleti Trauth, $4 \times$.

Figure 26 Section 2, 89-91 cm: Lamellaptychus submortilleti Trauth, $4 \times$.

Figure 27 Section 2, $91.5 \mathrm{~cm}$ : Lamellaptychus aff. oceanicus, $2 \times$. 
PLATE 1
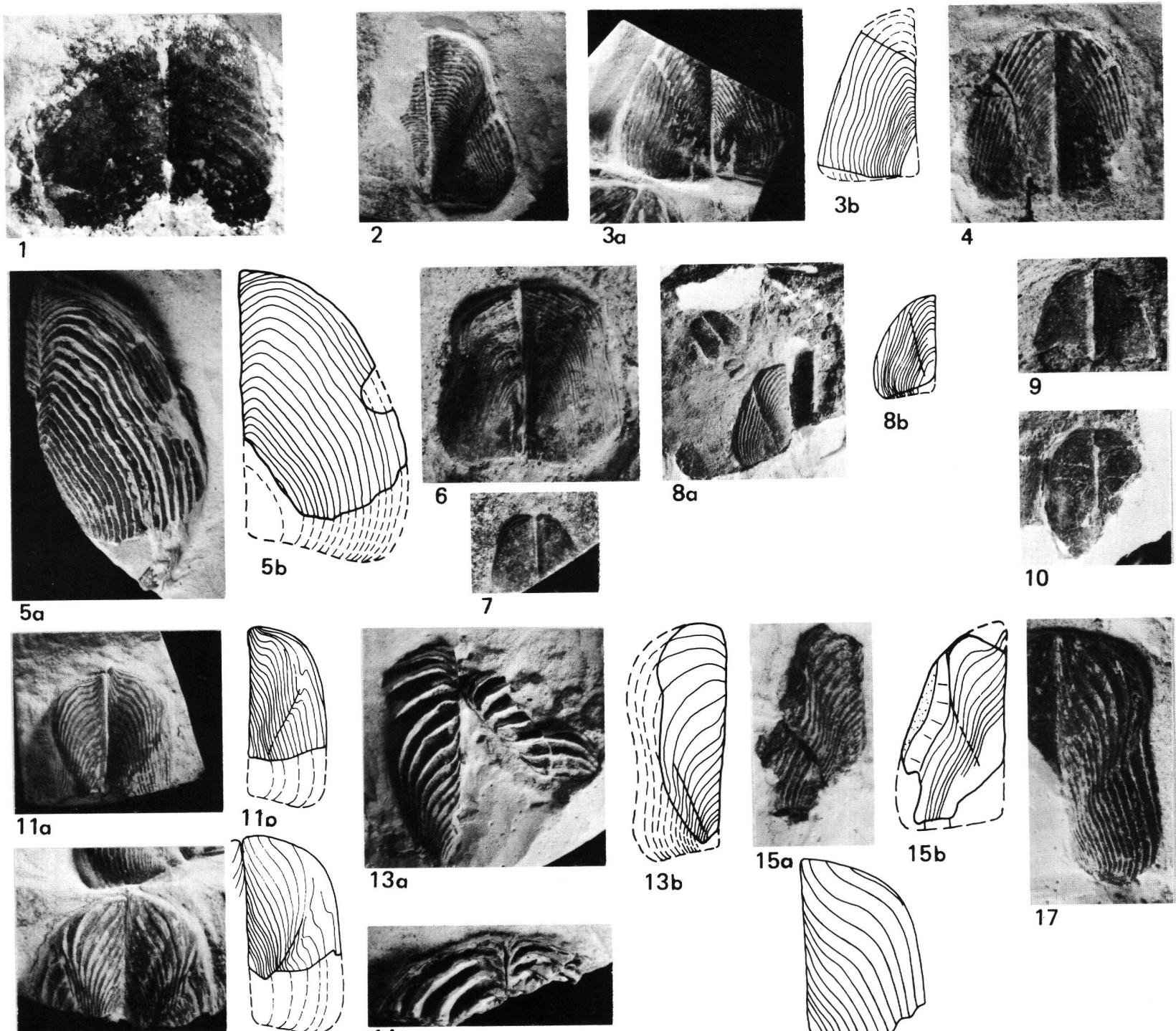

$12 a$

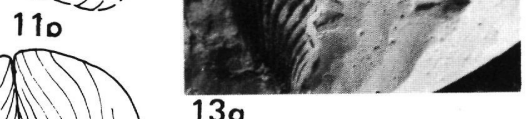

$8 a$
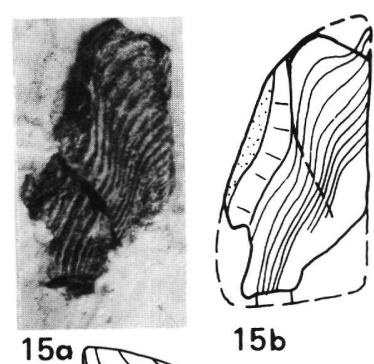

10
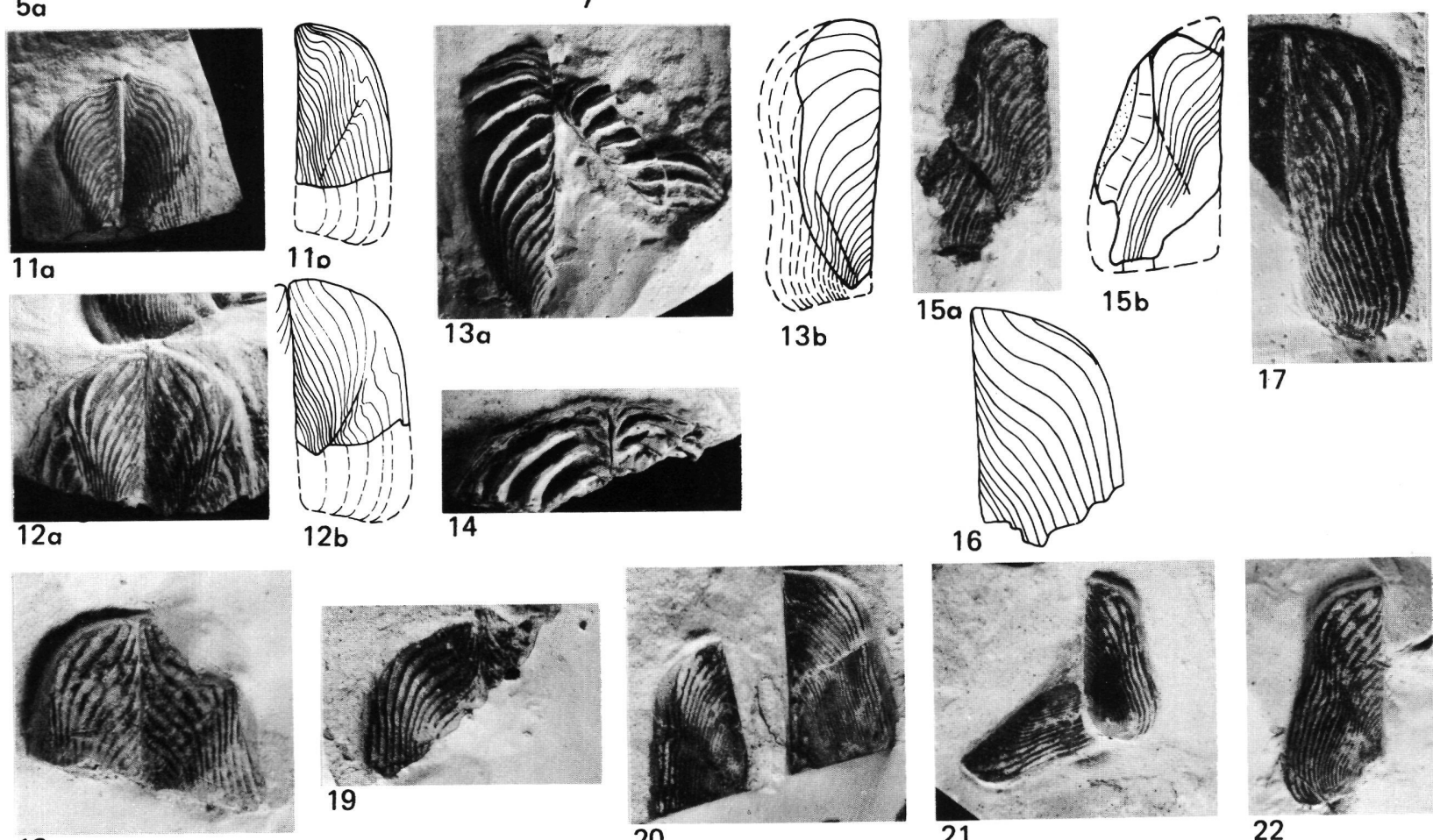

19
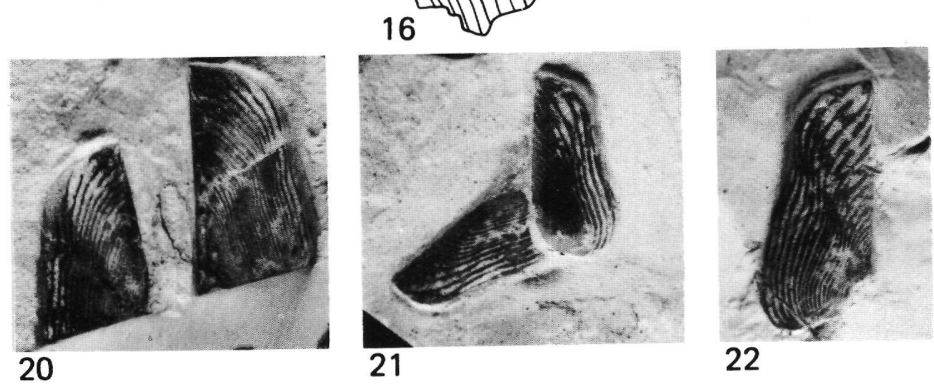

18
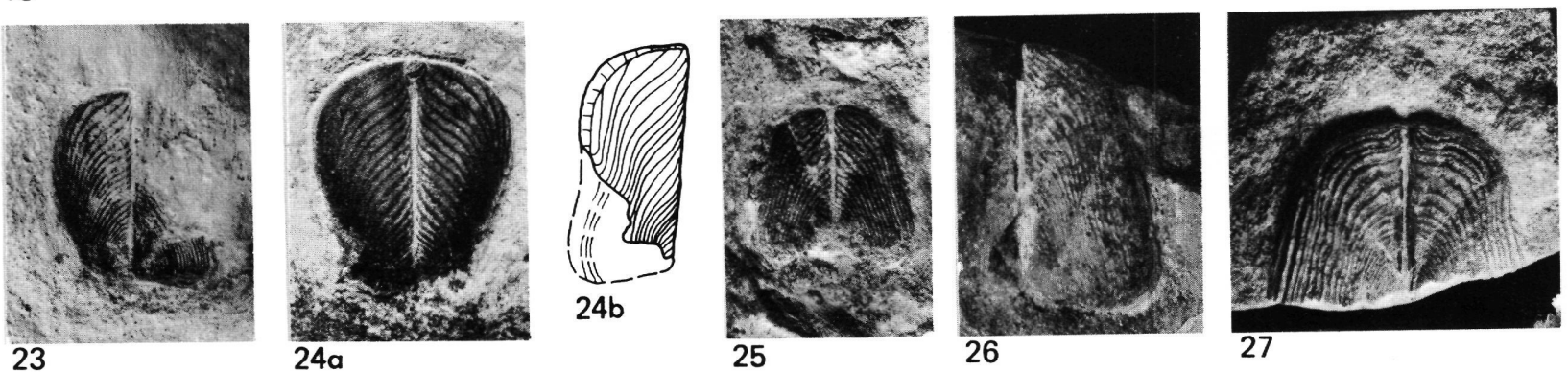